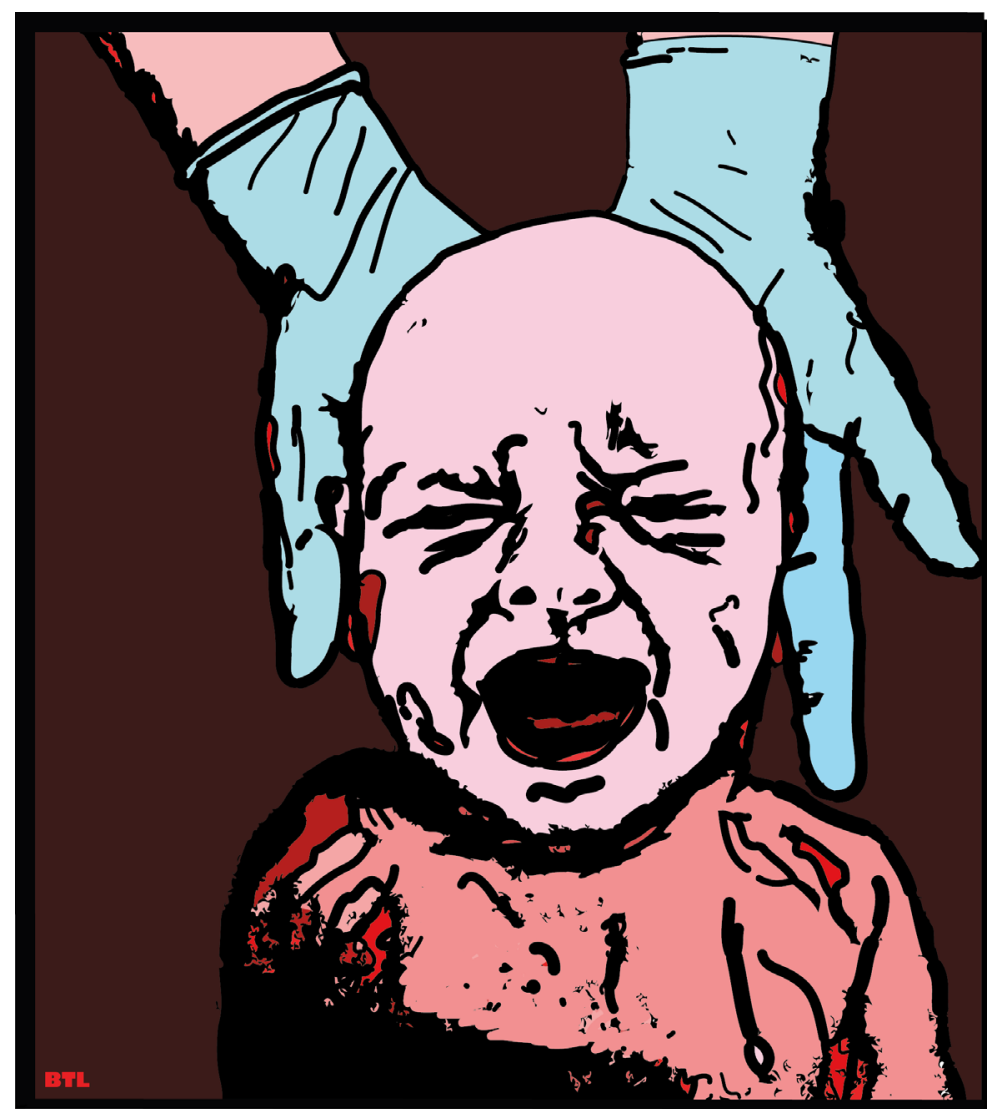

\title{
THE BIRTH
}

The Birth

Benjamin Laut 